\title{
The modality effect of working memory training on attentional function of children with attention-deficit/hyperactivity disorder in CANTAB
}

\author{
Talieh Sheykh Fendreski ${ }^{1}$, Alireza Moradi²,3* 1 , Mohamad Effat Panah ${ }^{4}$, Meysam Sadeghi $^{5}$
}

1. PhD Student in Cognitive Psychology, Department of Cognitive Psychology, Institute for Cognitive Science Studies, Tehran, Iran

2. Professor of Clinical Psychology, Department of Clinical Psychology, Kharazmi University, Tehran, Iran

3. Professor of Clinical Psychology, Department of Cognitive Psychology, Institute for Cognitive Science Studies, Tehran, Iran

4. Associate Professor of Child and Adolescent Psychiatry, Ziaeian Hospital, International Campus, Tehran University, Tehran, Iran

5. Assistant Professor of Assessment and Measurement, Department of Cognitive Psychology, Institute for Cognitive Science Studies, Tehran, Iran

Recieved: 9 Jan. 2020

Revised: 17 May. 2020

Accepted: 10 Jun. 2020

\section{Keywords}

Working memory training

Modality

Attention deficit disorder with hyperactivity

\section{Corresponding author}

Alireza Moradi, Professor of Clinical Psychology, Department of Clinical Psychology, Kharazmi University, Tehran, Iran

Email: Moradi@khu.ac.ir

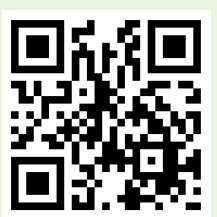

dol doi.org/10.30699/icss.22.2.33

\section{Abstract}

Introduction: Modality and how information is presented are among the most influential factors in attention processing, memory and learning. Even though children with ADHD show deficits in receiving integrated information from the visual and auditory systems and despite strong theoretical backgrounds, it has been less addressed in working memory interventions. Therefore, the effect of modality on working memory training in the near and far transfer was investigated through two Cambridge Neuropsychological Test Automated Battery (CANTAB) sub-tests.

Methods: This study was conducted as a 20-session intervention program on 61 children with ADHD in the age group of 8-12 years. They were evaluated by Spatial Working Memory (SWM) and Rapid Visual Information Processing (RVP) sub-tests. The subjects were divided into four groups: visual and auditory training groups and active and passive control groups. The intervention program included 40-60 minutes of working memory training for the training groups and 5-10 minutes for the active control group and no intervention for the non-active control group. Data were analyzed using multivariate analysis of covariance.

Results: Significant differences were observed in the post-test in both the visual and auditory groups in the sensitivity and bias (RVP), as well as total error index (SWM). However, in the use of strategy and reaction time, there were no significant differences.

Conclusion: Concerning the significant difference between training groups and control groups, the modality-based working memory training program seems successful. Also, the lack of significant difference between the visual and auditory groups indicates the same effect of both modalities on the near and far transfer.

Citation: Sheykh Fendeski T, Moradi A, Effat Panah M, Sadeghi M. The modality effect of working memory training on attentional function of children with attention-deficit/hyperactivity disorder in CANTAB. 2020;22(2):33-44. 


\title{
تاثير مداليته در آموزش حافظه كارى بر عملكرد توجه كودكان با اختلال نقصتوجه/بيشفعالى در آزمون CANTAB
}

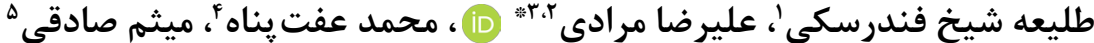

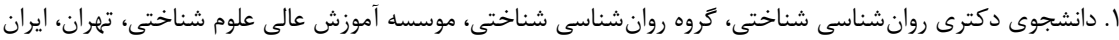

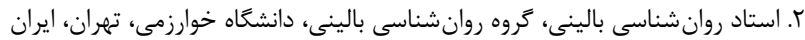

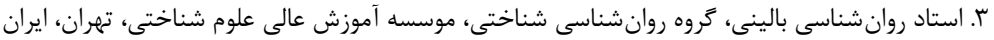

\section{ars}

مقدمه: مداليته و نحوه ارائه اطلاعات، يكى از مداخله كرهاى اثرگذار بر بردازشهاى توجهى، حافظه كارى و يادگيرى است كه گَرجه از يشتوانهاى نظرى محكمى برخوردار است اما در مداخلههاى حافظه كارى، كمتر به آن برداخته شده است. اين در حالى است كه كودكان با اختلال نقصتوجه و بيشفعالى، در دريافت يكيارجه اطلاعات از سيستمهاى ديدارى و شنيدارى با مشكل مواجهه هستند. از اين رو، يروهش حاضر با هدف بررسى تأثير مداليته و نحوه ارائه اطلاعات در حافظه كارى بر دو انتقال دور و نزديك از طريق دو خرده آزمون CANTAB انجام شد. روش كار: اين مطالعه در قالب يك طح آزمايشى •r جلسهاى بر روى او كودى با اختلال نقصتوجه و بيشفعالى در كروه سنى ז1 -1 سال اجرا و از طريق دو خرده آزمون حافظه كارى ديدارى/فضايى و بردازش سريع اطلاعات ديدارى انجام كرفت. كروه نمونه شامل جهار گروه آموزش ديدارى، آموزش شنيدارى، كنترل فعال و غيرفعال بودند. مداخله شامل .9ها دقيقه آموزش براى كروههاى ديدارى و شنيدارى، • (ا-ه دقيقه براى گروه كنترل فعال و نبود مداخله در كروه كنترل غيرفعال بوده است. تحليل دادهها با استفاده از آزمون تحليل كوواريانس جند متغيرى انجام شد. يافته ها: نتايج نشان داد كه تفاوت معنادارى در متغيرهاى حساسيت به محرى و سوكيرى به پاسخ از آزمون بردازش سريع اطلاعات ديدارى و خطاى كلى از آزمون حافظه كارى ديدارى/فضايى، در هر دو كروه ديدارى و شنيدارى در پِ آزمون وجود دارد، اما در استفاده از راهبرد و زمان واكنش، تفاوت معنادارى وجود نداشت. نتيجه گيرى: برنامه آموزش حافظه كارى مداليته محور، با توجه به تفاوت معنادار بين كروههاى آموزش و كنترل اثركذار بوده است. همجنين نبود تفاوت معنادار بين دو كروه ديدارى و شنيدارى، از اثر يكسان هر دو مداليته بر انتقال دور و نزديك خبر مى دهد.

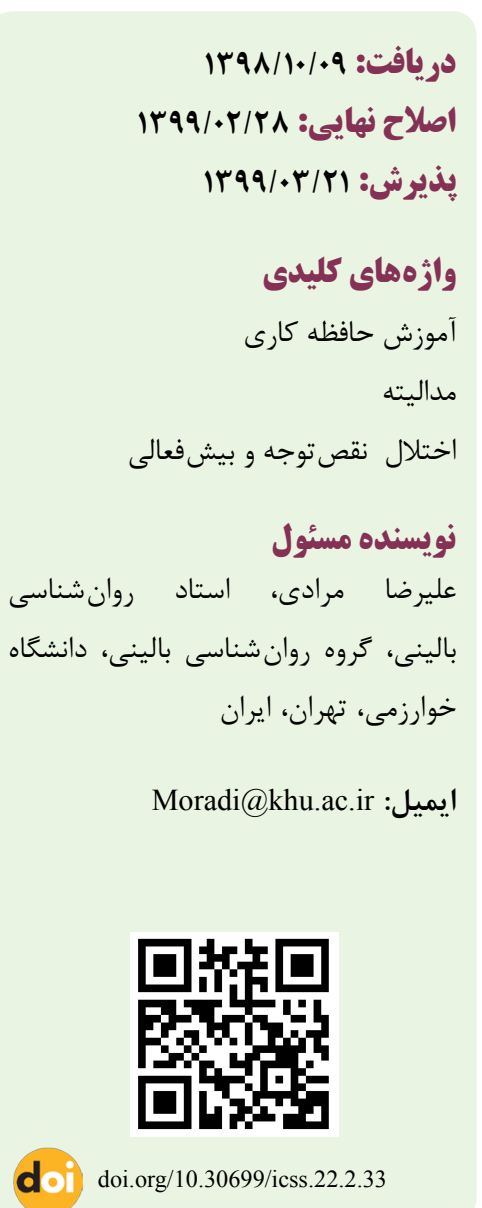

ايران بر مبناى نظر والدين آه/ه درصد و از نظر مربيان آ آ آ درصد ارزيابى شده است كه بالاتر از آخرين آمار شيوع جهانى آن (T/· درصد) است (r). كودكان مبتلا به اين اختلال عمومأ با وجود هوش بهر طبيعى، توانايى يادگيرى كمى دارند و به صورت ثانويه مستعد بسيارى از اختلال هاى روانشناختى هستند (ب). اغلب يُروهشگران نقص مركزى
اختلال نقصتوجه/بيشفعالى يكى از شايعترين اختلالهاى عصب تحولى روانيزشكى است و علائم بالينى آن بر اساس ويراست ينجم راهنماى تشخيصى و آمارى اختلالهاى روانى (DSM-5) به دو دسته اصلى بىتوجهى و تكانش گرى ابيشفعالى تقسيه مىشود. آخرين آمار شيوع جهانى اين اختلال r/• إ درصد است (1)، شيوع اين اختلال در 
تنها در ايجاد بار شناختى اثر كذارتر است (ه|)، بلكه بيشتر تحت تاثير عوامل حواس يرتى قرار مى يرد اين دو عامل مىتواند در محيطهاى

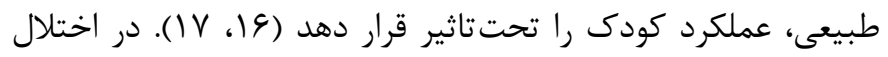

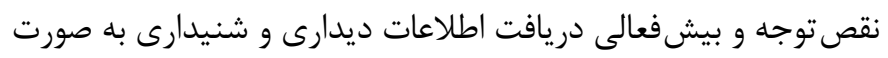

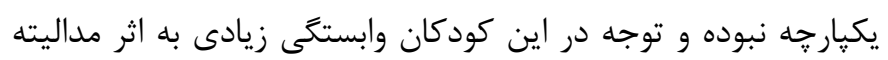

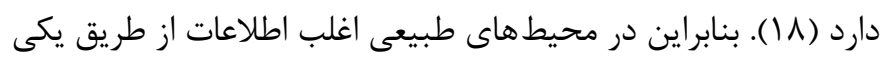

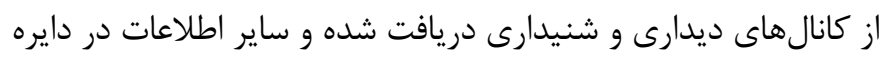

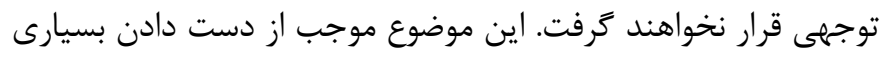
از اطلاعات و يادكيرى نامنسجم در اين كودكان مىشود. با اين حال، اغلب مطالعات پيشين به حافظه كارى بينايى توجه داشتهاند و آموزش حافظه كارى به صورت شنيدارى تا حد زيادى ناديده كرفته شده است، اين در حالى است كه افراد در دريافت اطلاعات تنها به يك مداليته

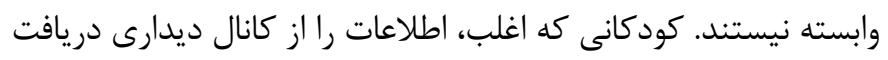
مى كنند و اطلاعات شنيدارى را به طور عمده از دست مى دهنيند، احتمالا

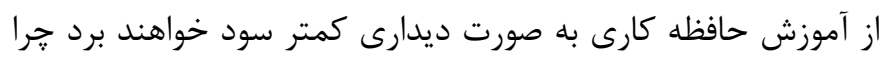
كه همجنان در دريافت اطلاعات محيطى از طريق شنيدارى ناتوان

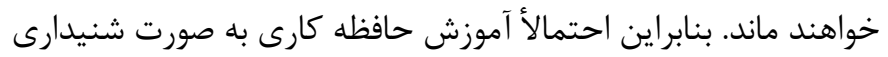

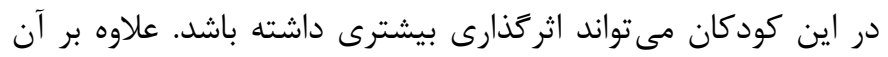
معدود مطالعاتى كه به اثر مداليته در آموزش حافظه كارى ثرداخته بودند نواقصى خون زمان كم اجراى مداخله و عدم استفاده از رويكرد بنيادين در طراحى مطالعه داشتهاند كه در اين مطالعه به آنها توجه مانه

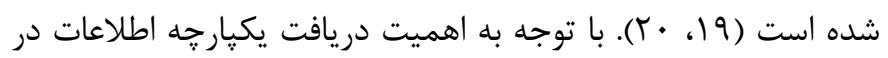

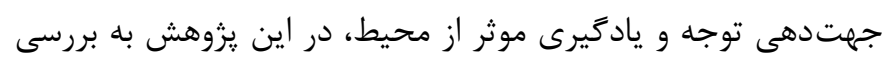

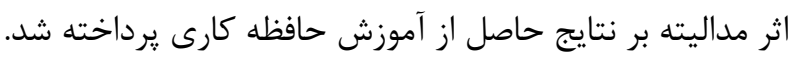

\section{روش كار}

مطالعه حاضر از نوع مداخله مقطعى بود كه در قالب يك طرح نيمه

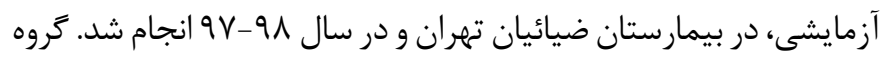

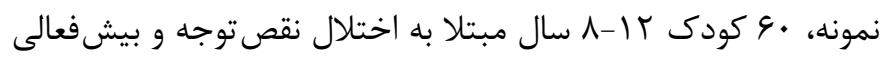

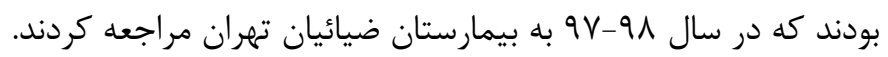

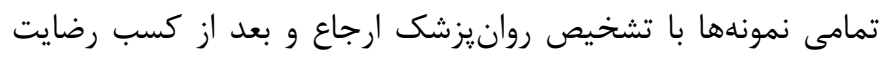

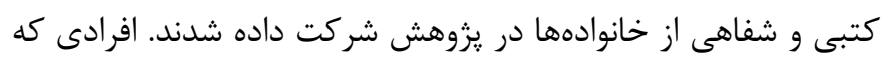

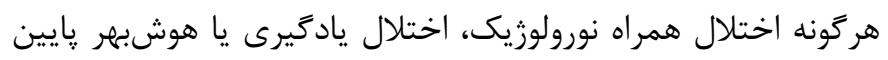

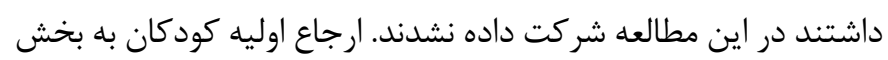
تكامل توسط روانيزشكان بيمارستان صورت گرفت. در ابتدا مصاحبه بالينى K-SADS با حضور كودى و والد اجرا و بعد از اطمينان از تشخيص، براى بررسى ميزان غلبه توجه ديدارى و شنيدارى و تشخيص
در اختلال بيشفعالى/تكانش گرى را در عملكرد لوب پيشانى مىدانند كه مسئول كنترل مهارى، تنظيم توجه و حافظه كارى است و نقايص

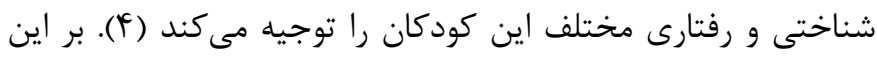
مبنا عوامل شناختى كه در اين اختلال بيش از همه قابل مشاهدهاند،

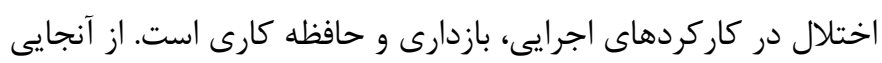

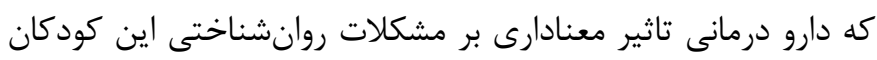

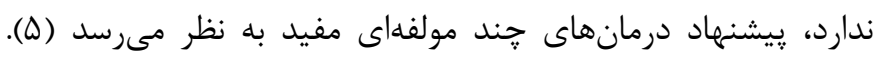

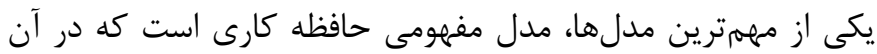

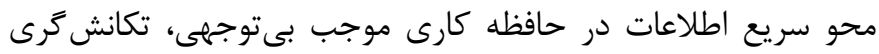
و عدم سازماندهى مىشود. مداخلات مبتنى بر اين نظريه، دو مولفه

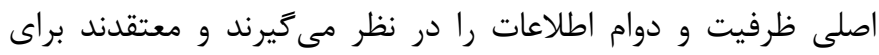

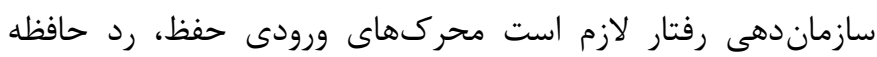
براى ييدا كردن ميزان مشابهتها جستجو و در نهايت بر مبناى مئان ميزان

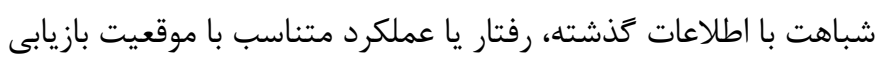

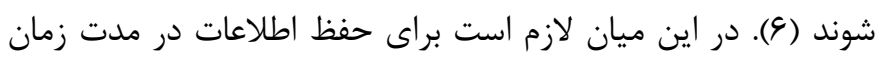

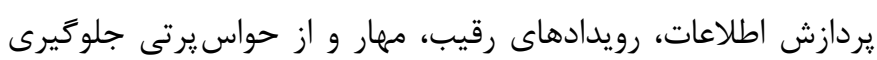

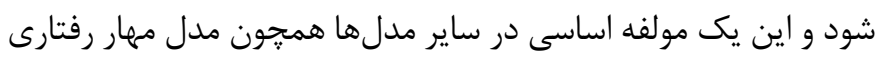
Barkley رفتار را شكل مىدهد (V) (V).

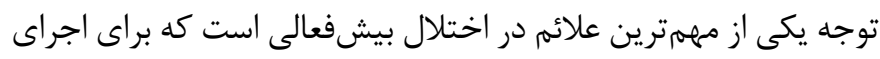

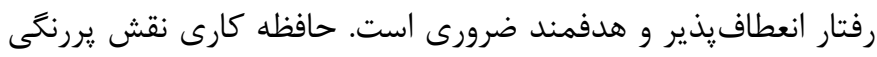

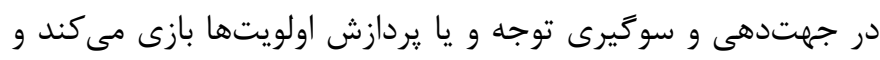

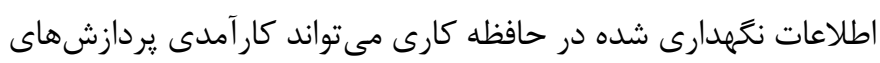

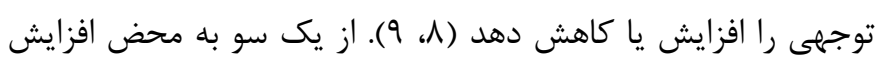

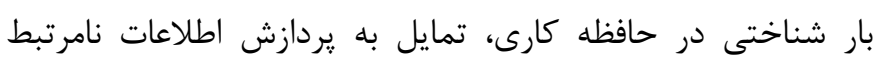
بيشتر شده و شناسايى هدف و يردازش اولويتها مبهرم مىشوند كه نشان دهنده افزايش فعاليت قشر حسى مرتبط با محرك است و نتيجه آن تداخل رفتارى نسبت به عوامل حواسيرتى خواهد بود (•(). به

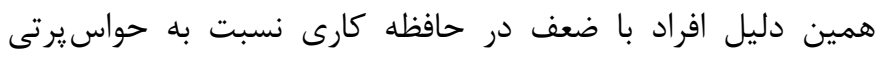

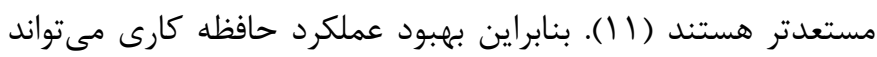

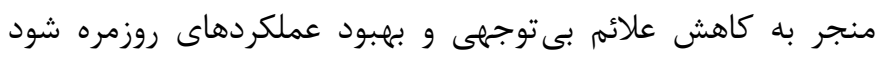

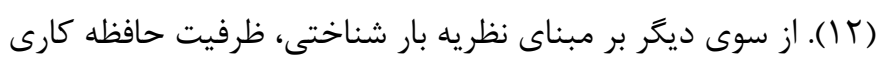

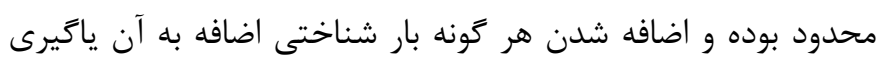

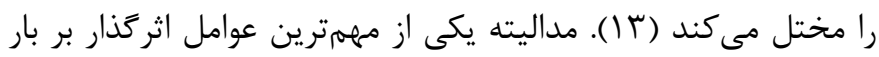

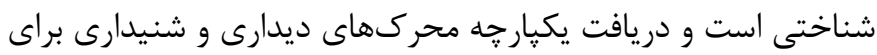

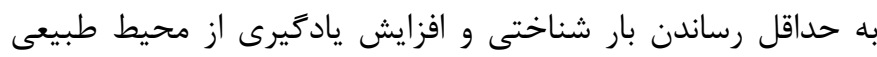
ضرورى به نظر مىرسد (أl). به نظر مىرسد كه مداليته شنيدارى نه 
تكليف N-back: اين تكليف شامل مقايسه مداوم محرك حاضر با محرك قبل است و براى اجرا به نظارت بر محركهاى ورودى، حفظ اطلاعات در عين حال مهار اطلاعات نامرتبط، بروزرسانى و انتقال نياز

تكليف مقايسه دو فهرست: مواد داخل هر فهرست به صورت جداكانه

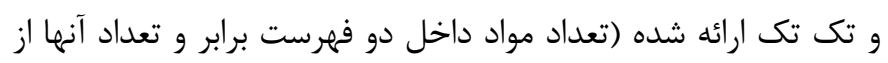

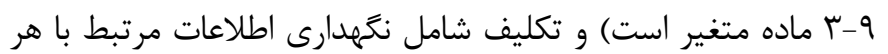

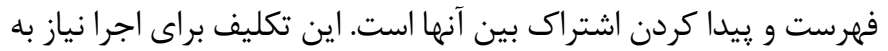
حفظ و دستكارى اطلاعات، مهار ياسخهاى نامرتبط و ايجاد اتصال بين شىء (Binding Object to Context) و زمينه مربوط به خود دارد كه يكى از عوامل محدودكننده ظرفيت حافظه كارى محسوب مىشود (Y). تكليف بازشناسى فضايى: اين تكليف شامل به يادسيارى شكل،

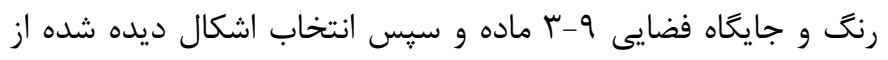

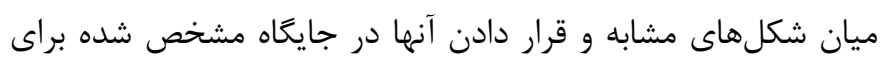

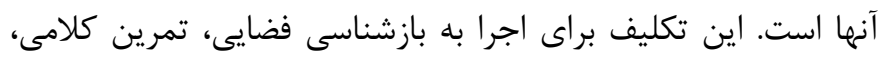

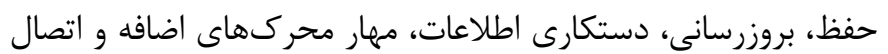
r مشخصه به هم نياز دارد.

تكليف كدكذارى: اين تكليف شامل به ياد سيارى محرك نشانه (يكى از حروف الفباى فارسى) و محرك هدف (اعداد مربوط به هر حرف) و

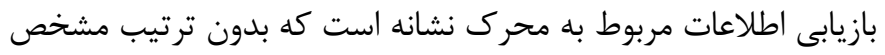
ارائه خواهند شد. براى اجرا علاوه بر حفظ و دستكارى اطلاعات، به ياد كيرى تداعى، سرعت يردازش و هوش كلامى نياز است. تكليف ماز: اين تكليف نسخه فضايى تكليف گستره ارقام بوده و شامل نياز به يادسيارى جهت حركت به صورت مستقيه و معكوس است و براى اجرا جهت يابى فضايى، حفظ و دستكارى اطلاعات ضرورى هستند.

ابزارها

مصاحبه تشخيصى نيمه ساختاريافته اختلالهاى خلقى و اسكيزوفرنى براى كودكان و نوجوانان، تشخيص فعلى و طول عمر (K-SADS): اين ابزار يك مصاحبه نيمه ساختاريافته براى

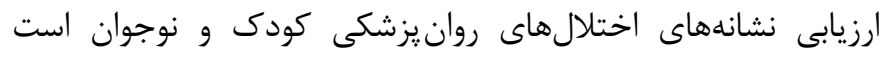

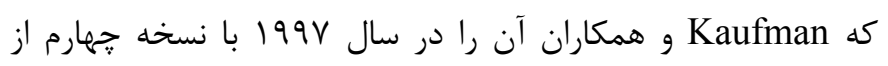

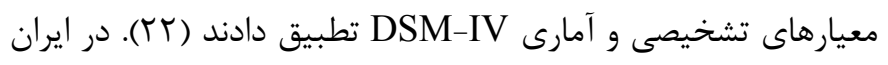

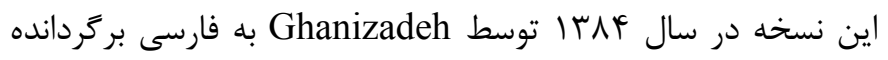

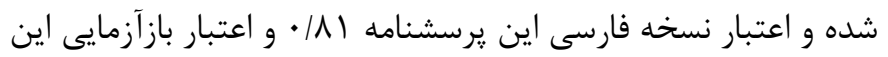
آزمون 99/• تزارش شده است (سT). اين مصاحبه نيمه ساختاريافته با در نظر گرفتن والدين، كودى و مصاحبه كننده تكميل مى كردد. در بخش اول اكر ب نمره از ع سوال اوليه كسب شود، بخش ضميمه اختلال
نوع بيشفعالى، كودكان در آزمودن IVA-2 شركت كرده و بر اين

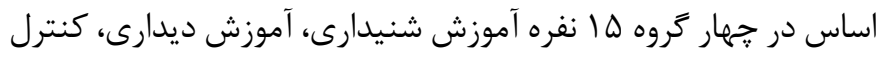

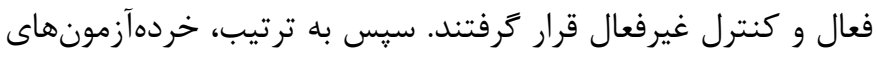
تكليف جستجوى حركتى (Motor Screening Task) براى اطمينان

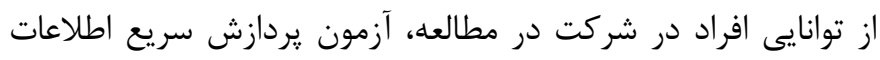

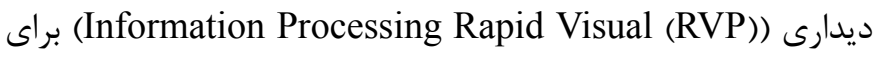
برسى توجه پايدار و آزمون حافظه كارى فضايى Memory (SWM) براك

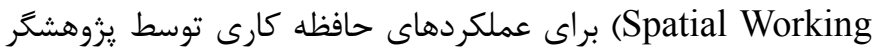
اجرا شدند. جلسات مداخله توسط جهار روانشناس بالينى آموزش ديده در بخش تكامل بيمارستان ضيائيان بركزار شد. فاصله شركت كنند تا نمايش

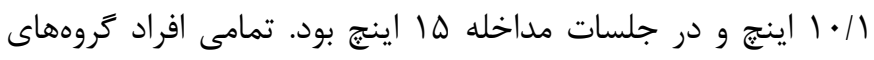

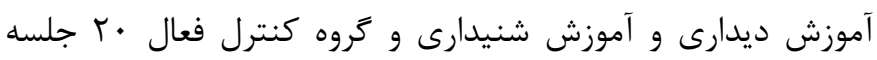

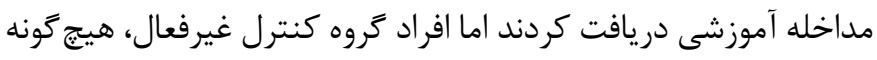

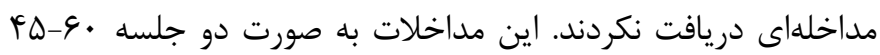

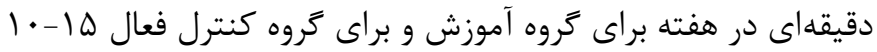
دقيقه اجرا شد. تمامى شركت كنندگان در هر زمانى از مداخله، مجاز به خروج از طرح بودند. بعد از اتمام مداخله، نمونهها بار ديخر ارزيابى

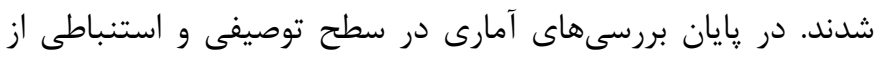

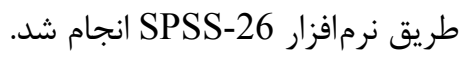

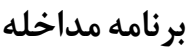

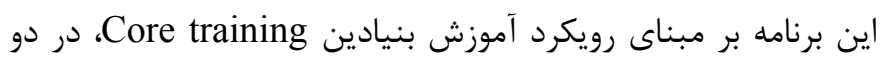

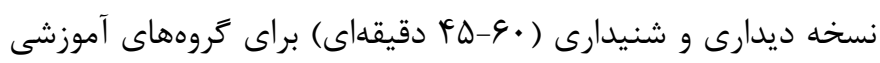

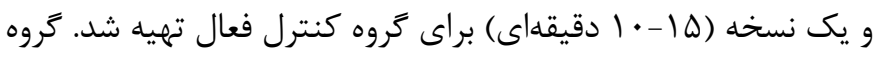
كنترل فعال تمامى تكاليف مشابه با كروههاى آزمايش را اجرا مى كنند با اين تفاوت كه زمان اجرا تكاليف كمتر بوده است. مجموعهاى از هفت تكليف شناخته شده حافظه كارى به شكل انطباق يذير طراحى و در اين

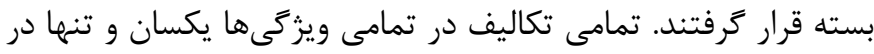

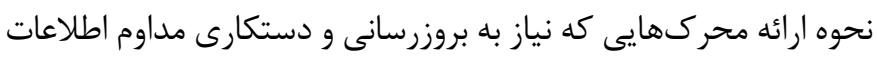
داشتند، متفاوت بودند. اين تكاليف شامل: فراخناى ارقام معكوس: اين تكليف شامل بازيابى معكوس ب تا تا 9

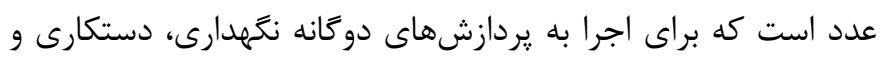
بروزرسانى مداوم اطلاعات نياز دارد.

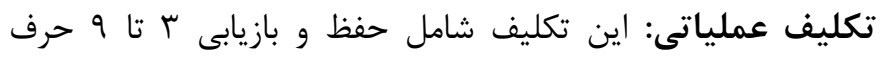

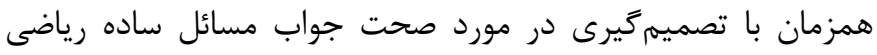
به عنوان محرك اضافه است و براى اجرا به حفظ، تمرين كلامى، مهار محرك نامرتبط، بروزرسانى و انتقال آمايه نياز دارد. 


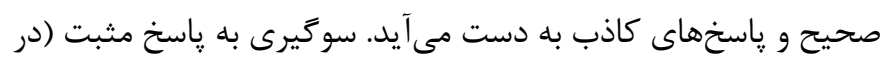

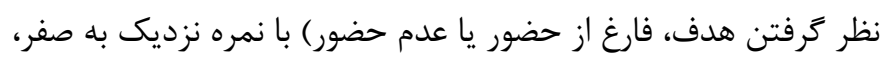

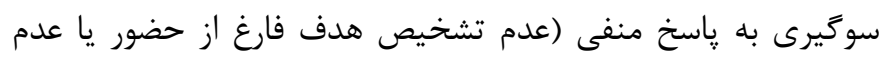

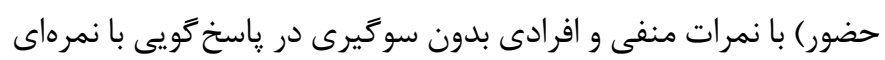

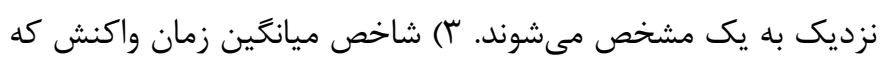

به معناى ميانكين زمانى صرف شده براى ياسخ صحيح است.

\section{آزمون حافظه كارى فضايى (SWM))} Spatial

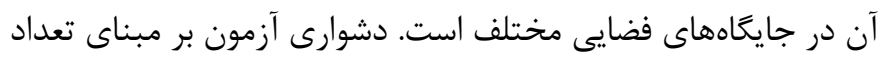
جعبهها تعيين مىشود. شاخصهاى استفاده شده در اين آزمون شامل: () شاخص خطاى كلى كه شاخصى است از ظرفيت حافظه كارى و از

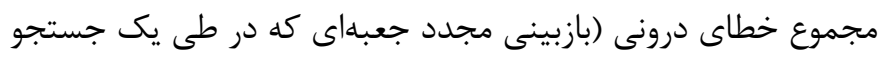

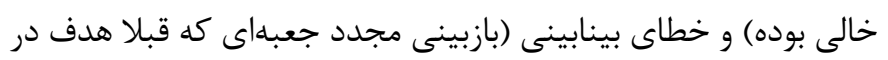

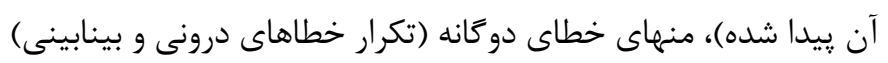

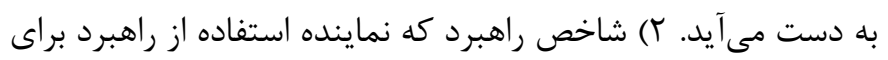

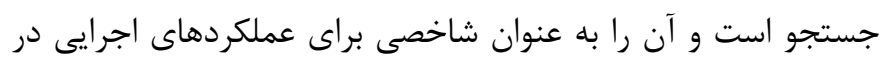

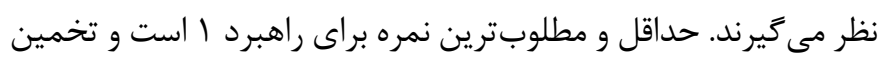

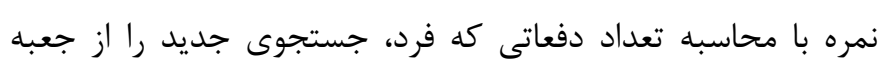
نامشخص شروع كند به دست مى آيد.

يافته ها

در ابتدا ويزگى هاى جمعيتشناختى گروه نمونه، مورد بررسى قرار

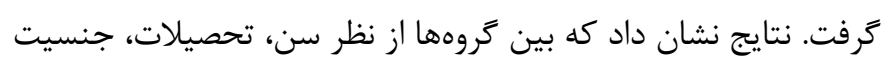
و نوع اختلال تفاوت معنادارى وجود ندارد (جدول () ).

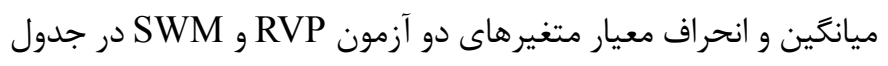

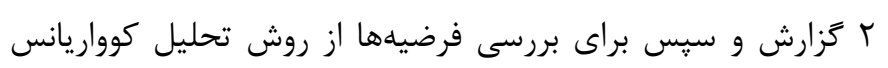

$$
\text { קند إند متغيرى استفاده شد. }
$$

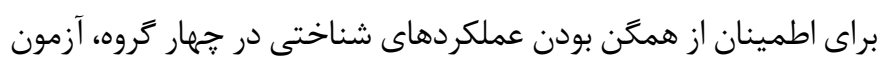

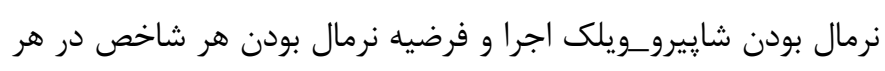

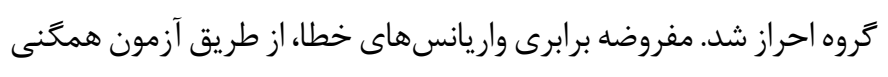
واريانسهاى لوين نيز در متغيرهاى مورد بررسى قرار كرفت و تأييد شد.

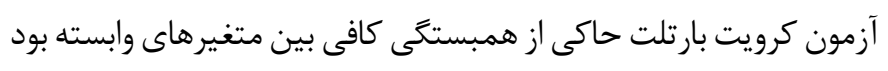

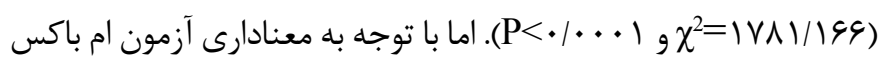

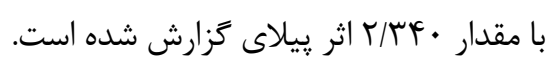

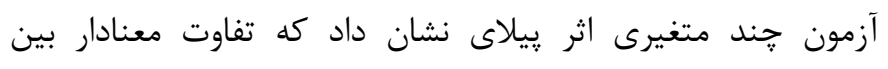

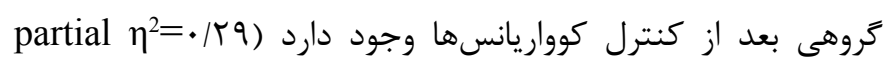

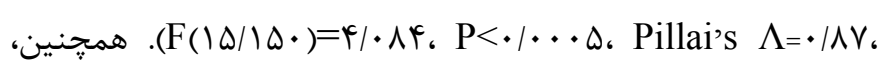

رفتارى بيشفعالى كه شامل · · سوال است تكميل مىشود. در انتها

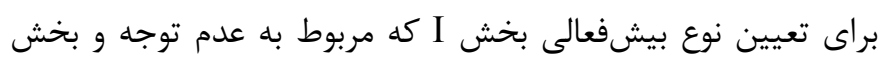

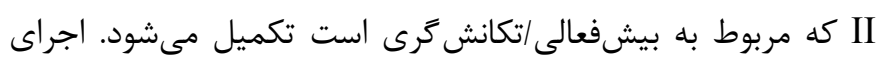

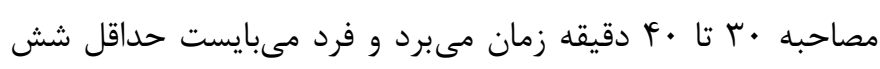

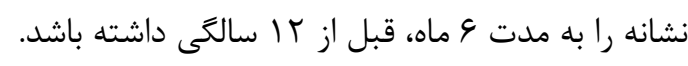

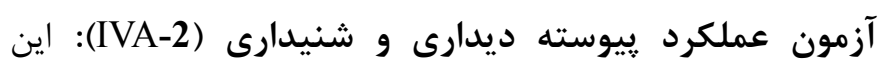

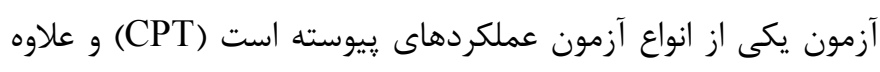

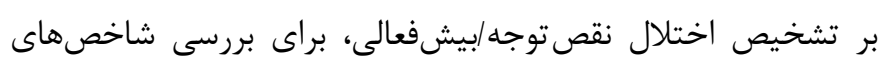

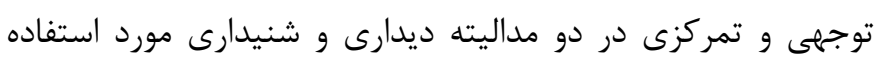

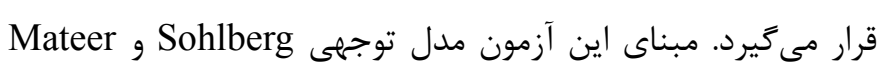

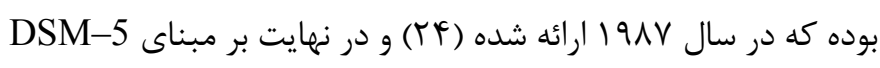
تدوين شد است. شواهد يزوهش حاكى از آن است كه حساسيت اين

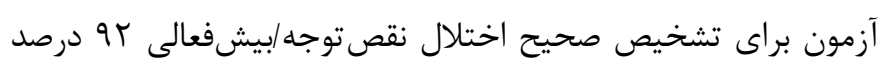

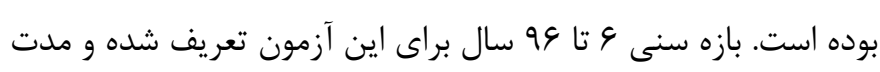

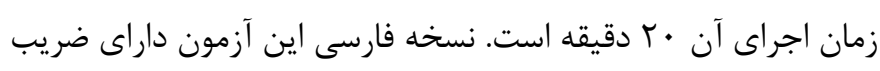

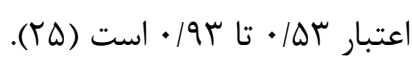

\section{Test Automated Battery (CANTAB))} 191 • Cambridge Neuropsychological

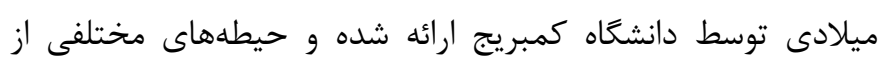

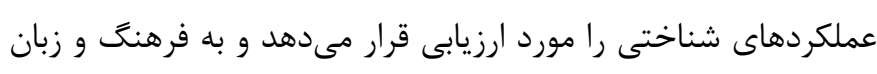

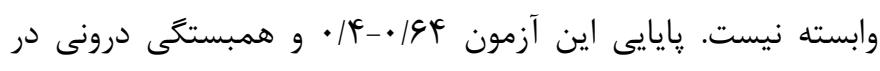

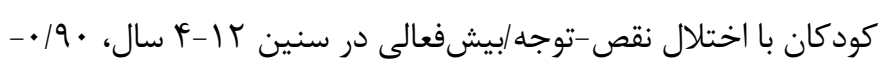

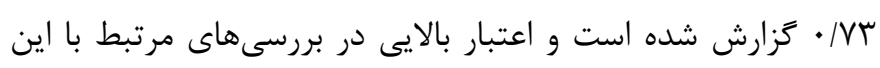

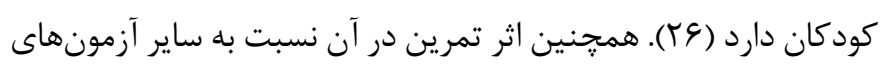

$$
\text { عصب روانشناختى كمتر است (TV) }
$$

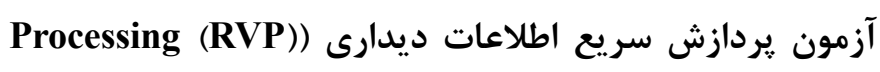
Rapid Visual Information

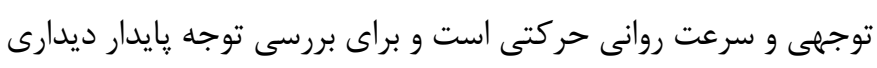

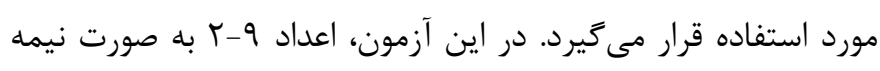

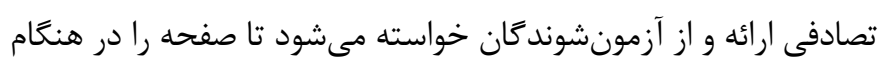
تشخيص توالى سه رقمى از اعداد لمس كنند. زمان اجراى آزمون 9

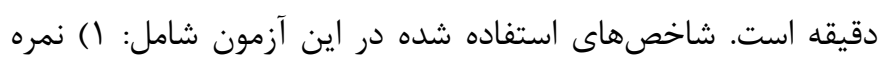

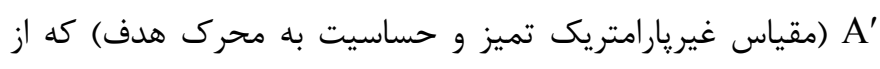

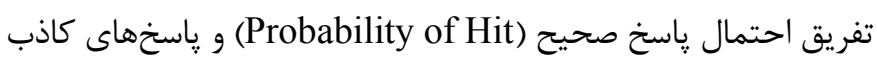
به دست مى آيد و عددى است بين (Probability of False Alarm) صفر )حداقل تميز و حساسيت) و يك (حداكثر حساسيت به محرك).

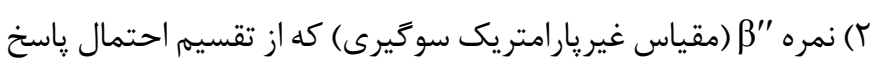




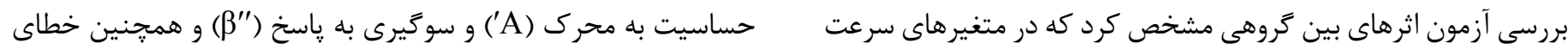

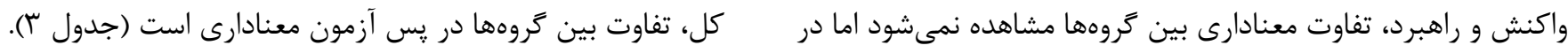

جدول ا. اطلاعات جمعيت شناختى

\begin{tabular}{|c|c|c|c|c|c|c|}
\hline شاخصهاى آمارى & كنترل غيرفعال & كنترل فعال & آموزش ديدارى & آموزش شنيدارى & \multicolumn{2}{|c|}{ متغير } \\
\hline $\mathrm{F}=\cdot / V \Delta T_{،} \mathrm{P}=\cdot / \Delta T \phi$ & $(1 / \Gamma V) 9 / 1 \Lambda$ & $(1 / 09) 9 / 4 r$ & $(1 / 11) 9 / 99$ & $(1 / \Gamma \Delta) 9$ & \multicolumn{2}{|c|}{ سن } \\
\hline \multirow{4}{*}{$\chi^{r}=\cdot / 11}$. & F F & א א א درصد & س/ ז/ درصد & F F & دوم & \multirow{4}{*}{ تحصيلات } \\
\hline & ك/r/ ادرصد & T Tد Tدصد & 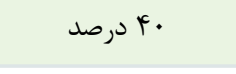 & 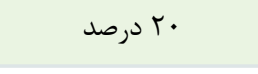 & سوم & \\
\hline & 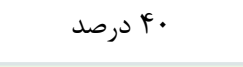 & ل & 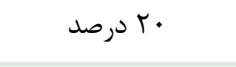 & T Y Y درصد & جهارم & \\
\hline & - & T & V Y Y درصد & ل & ينجم & \\
\hline \multirow{2}{*}{$\chi^{\Upsilon}=\cdot / \uparrow \vee \varepsilon$} & •l) & ᄉ (T/س/ ه درصد) & 11 ( 1 (ז/r درصد) & $(\xi \& / V) V$ & ADD & \multirow{2}{*}{ وع اختلال } \\
\hline & 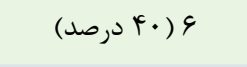 & ( ) V & ( & ᄉ 1 ( & ADHD & \\
\hline \multirow{2}{*}{$\chi^{r}=\cdot 1 \Delta \cdot \Delta$} & ه (T//آ درصد) & r (r/ זادرصد) & ( & r/(I/ادرصد) & دختر & \multirow{2}{*}{ جنسيت } \\
\hline & || & זו (V/N درصد) & 11 (I/ & rا| (V/N درصد) & پِر & \\
\hline
\end{tabular}

جدول r. ميانگين و انحراف معيار آزمونهاى RVP و SWM

\begin{tabular}{|c|c|c|c|c|c|c|c|c|c|c|}
\hline رل غيرفعال & كروه كن & ترل فعال & كروه & \multicolumn{2}{|c|}{ كروه ديدارى } & \multicolumn{2}{|c|}{ كروه شنيدارى } & & \multirow{2}{*}{\multicolumn{2}{|c|}{ متغير ها }} \\
\hline انحراف معيار & ميانغين & انحراف معيار & ميانغين & انحراف معيار & ميانغين & انحراف معيار & ميانغين & & & \\
\hline $1.1 / 89$ & $\varepsilon \Delta r / \varepsilon q$ & $|\varepsilon r / T|$ & $V \wedge F / \mu I$ & $191 / 14$ & $v r \cdot / r q$ & TIF/s & $819 / 19$ & ييش آزمون & & \\
\hline $19 \cdot 119$ & $V \Delta I / \cdot$. & TMY/AF & $81 \cdot 119$ & $1 \cdot V / \cdot \Delta$ & $\vee \cdot / 1 q$ & $\mid F q / 1 V$ & GGY/VA & يس آزمون & & \\
\hline $.1 \cdot f$ & $\cdot / V \wedge$ & $\cdot / \cdot 1$ & $\cdot / V \varepsilon$ & $\cdot / \cdot r$ & $\cdot / V \wedge$ & $\cdot / \cdot 1$ & $\cdot / V 9$ & ييش آزمون & & \\
\hline$\cdot 1 \cdot f$ & $\cdot / V G$ & .1 .9 & $\cdot / V 9$ & $\cdot / \cdot F$ & $\cdot / \Lambda \Delta$ & $\cdot / \cdot \Delta$ & $\cdot \mid \Lambda V$ & يس آزمون & & \\
\hline$\cdot \pi \cdot$ & .19. & זr/. & $\cdot|\Delta|^{F}$ & $\cdot / 49$ & $\cdot|9|$ & r & .194 & ييش آزمون & & \\
\hline$\cdot / T F$ & $\cdot / Q V$ & $\cdot / T r$ & $\cdot 18 \Lambda$ & $\cdot / \cdot r$ & .194 & $\cdot 1 \cdot \Delta$ & $\cdot \mid \Lambda V$ & يس آزمون & & \\
\hline I/VG & rN/Ir & $r / .$. & rN/rv & $r / 11$ & $r \cdot / 1 r$ & $\boldsymbol{F} / \mathrm{K} \Lambda$ & TV/TG & پيش آزمون & & \\
\hline$T / T \Lambda$ & שr/Tr & T/QT & $\mathrm{rV} / \mathrm{l \Lambda}$ & $T / \Delta F$ & $r q / 4$. & T/AV & $r \Delta / \cdot \cdot$ & يس آزمون & & \\
\hline $19 / 11$ & $\Delta \wedge / \wedge \epsilon$ & 11/Tr & GI/GY & $1 \pi / T s$ & $\Delta 9 / 49$ & $r \cdot 19$. & $\Delta T / \mathscr{C}$ & ييش آزمون & & Swin \\
\hline $11 / 1 \pi$ & $\Delta G / V \wedge$ & $I V / \Delta \Delta$ & $\Delta \cdot / V \Delta$ & $10 / 09$ & $r \Delta / \cdot \cdot$ & G/Tr & שץ/זr & يس آزمون & & \\
\hline
\end{tabular}


جدول r. آزمون اثرهاى بين گروهى و مقايسه متغيرهاى وابسته در پِ آزمون

\begin{tabular}{|c|c|c|c|c|c|c|c|}
\hline مجذورات & $\mathbf{P}$ & $\mathbf{F}$ & ميانكين مجذورات & Df & مجموع مجذورات & متغير ها & آزمونها \\
\hline$\cdot / \cdot \vee \wedge$ & $\cdot \pi r F$ & $1 / 491$ & 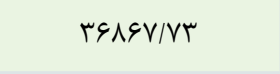 & r & $11 \cdot \Delta q F / r \cdot r$ & زمان واكنش & \multirow{3}{*}{ RVP } \\
\hline . MtT & $.1 . .1$ & $\mid r / v \cdot 1$ &.$/ . r q$ & r & .1119 & حساسيت & \\
\hline.$/ 4 \& V$ & $.1 . .1$ & $|\Delta /| 9 \mid$ & - RAV & r & I/194 & سو تيرى & \\
\hline.$/ 110$ & .1 .94 & T/TET & $I N / \Delta \Delta V$ & r & $\Delta \Delta / \& V T$ & راهبرد & \multirow[t]{2}{*}{ SWM } \\
\hline.$|\Delta| f$ & $.1 . .1$ & IN/TFY & $r \Delta F q / q \mid Q$ & r & VEYAIAFS & خطاى كلى & \\
\hline
\end{tabular}

دو كروه مداخله به عدد يك نزديك شده كه نشان دهنده اثر مداخله در

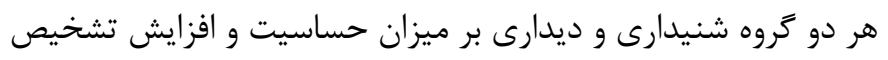
محرك هدف در طول زمان است.

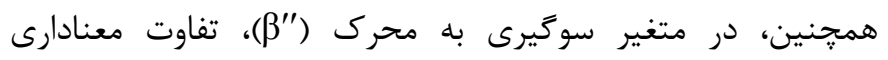

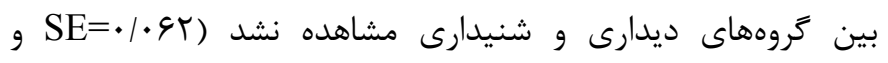

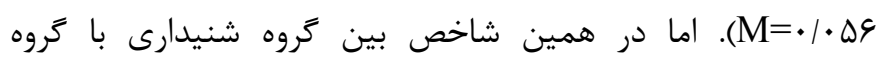

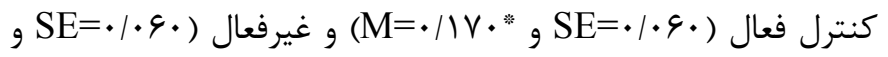

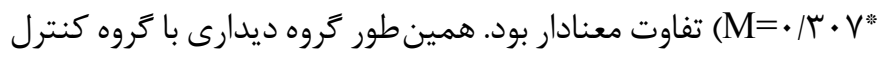
فع

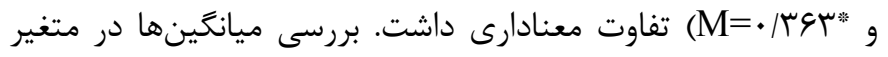
سوكيرى نشان داد كه سوكيرى به קاسخ مثبت يا منفى در دو گروه

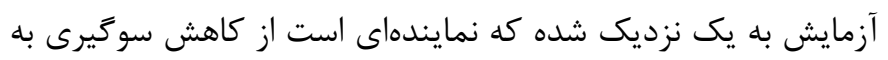
ياسخ (نمودار ()).

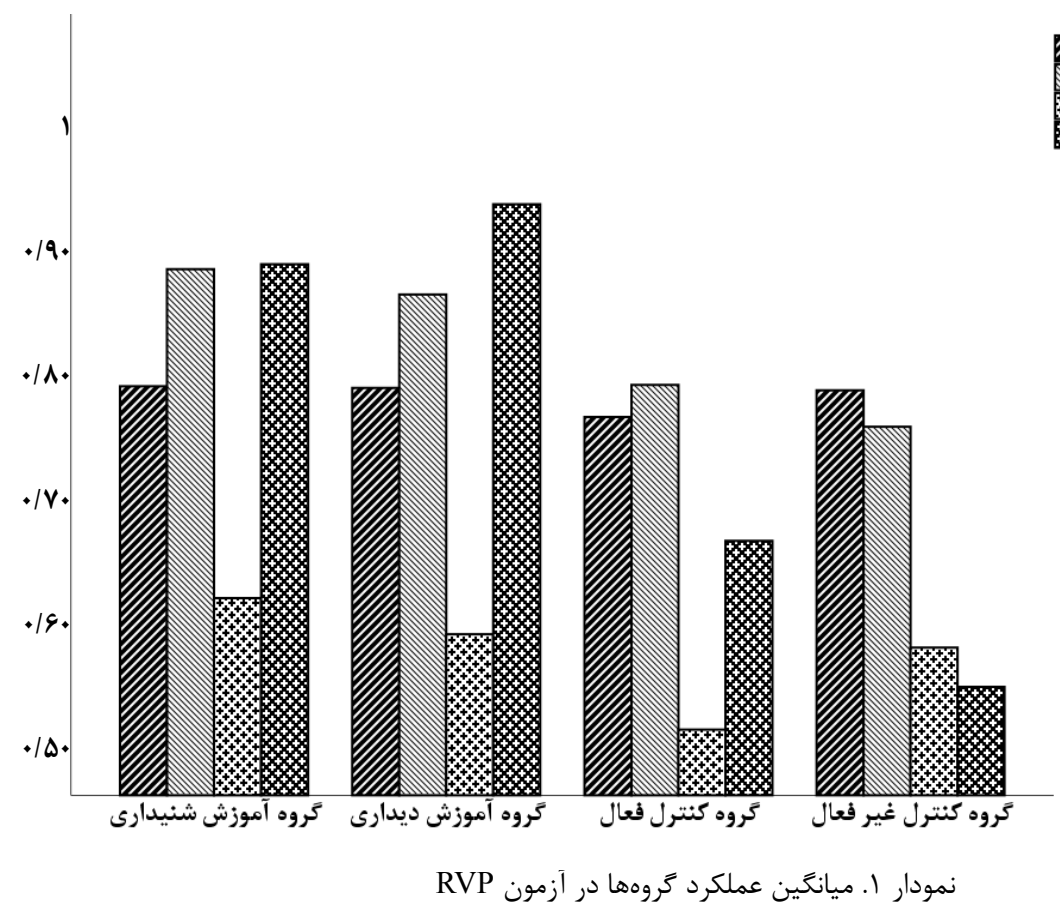

براى تعيين تفاوت بين گروهها در اين سه متغير وابسته، آزمون مقايسات

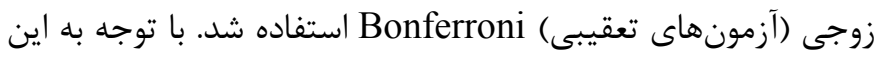
كه در متغير زمان واكنش در آزمون RVP و متغير إنغير راهبرد در آزمون SWM آتى حذف شدهاند (ه> P (P)

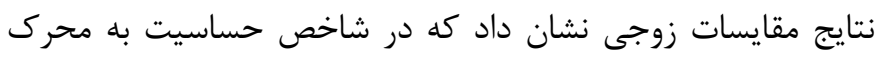

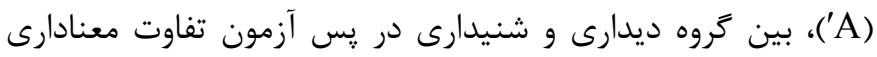

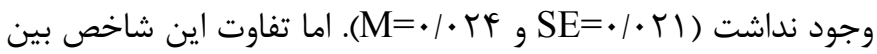

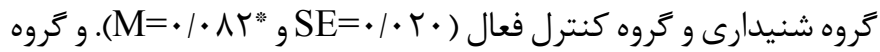

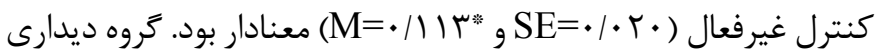

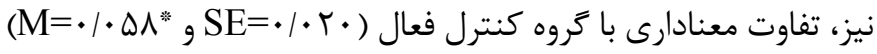

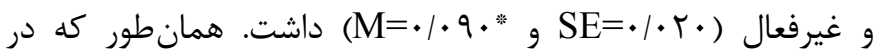

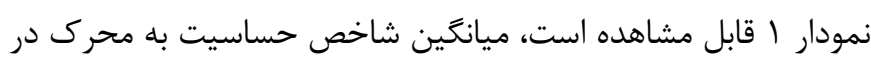


كروه ديدارى با كنترل فعال (SE= و و و

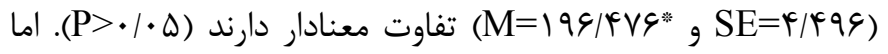
در بررسى شاخص راهبرد، تفاوت معنادارى بين هيج يك از خروهها

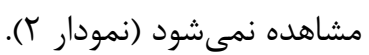

در شاخص خطاى كلى آزمون SWM، بين كروههاى آموزش ديدارى و شنيدارى تفاوت معنادارى مشاهده نشد (SE=F/DQI $S E=r / \% 94(M=9 / 99 \Delta$ و و و و و

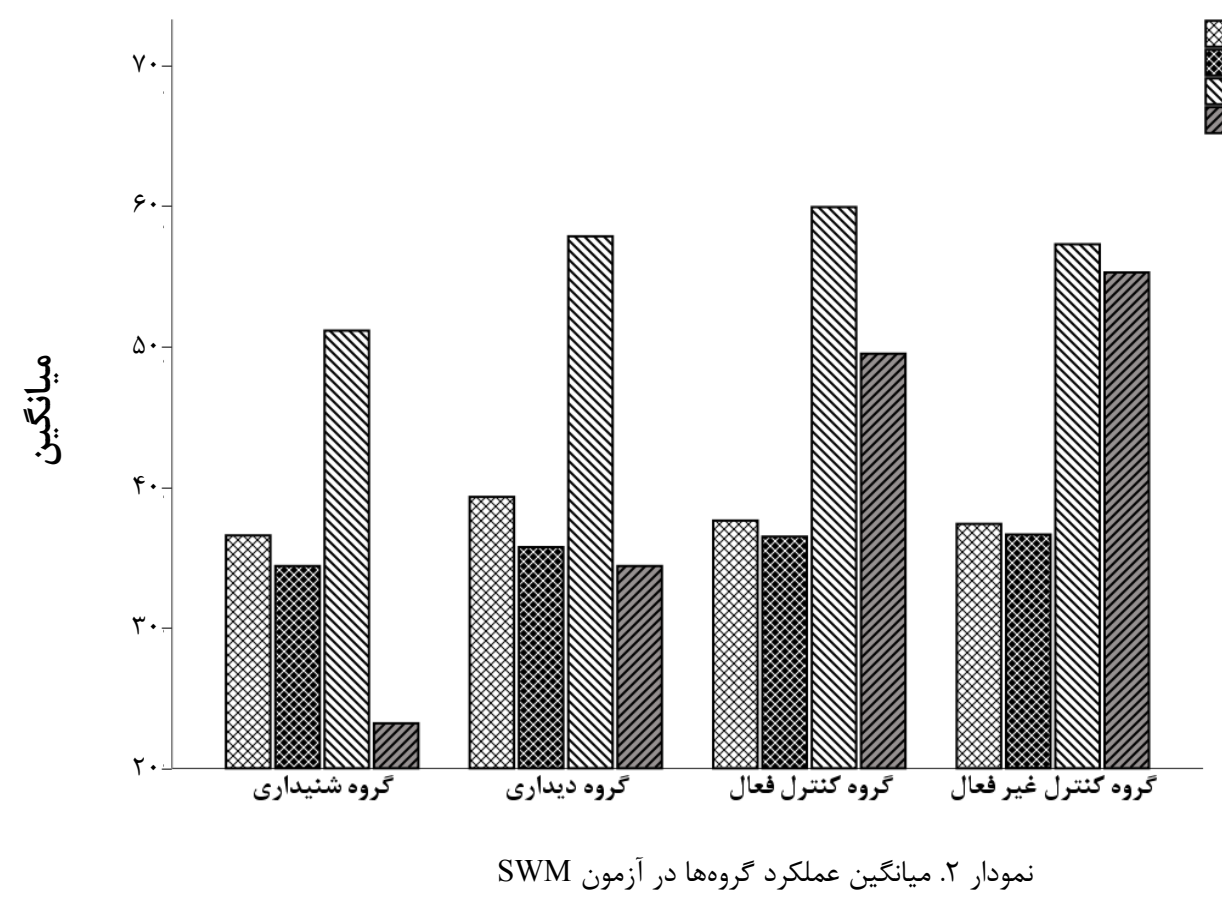

اين نوع از ارائه بر نتايج است. ماهيت كانالهاى يردازشى ديدارى و

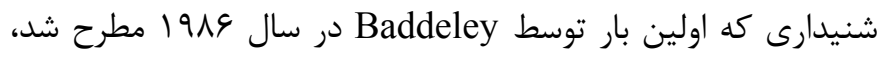

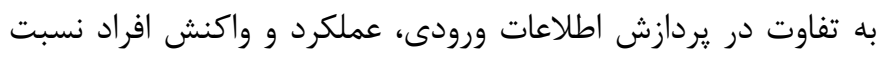

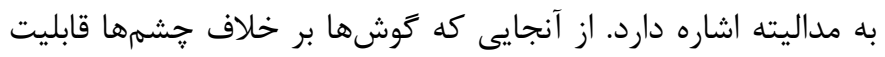
تمركز بر محرك هدف و يا بسته شدن را ندارند، محرك هاى شنيدارى حتى اكر يكسان نباشند، به طور همزمان وارد كَش شده و طبقهبندى، وزندهى و انتخاب اولويت در اطلاعات شنيدارى را دشوارتر مى كند ( آا). ملزومات اجراى كارآمد اين مداخلات، يردازشهاى سريع ديدارى و شنيدارى است كه افزايش ظرفيت و دوام اطلاعات در حافظه كارى

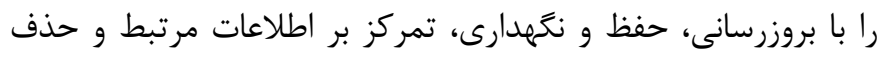

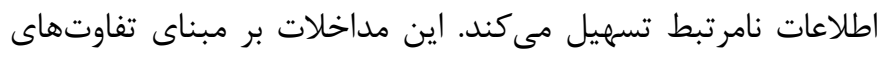

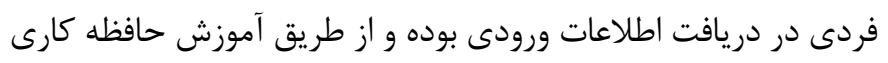
مداليته محور، به قرار كرفتن مداليته ضعيفتر در مركز توجه كمك مى كند. از طرفى، مطالعه Schneider كه يكى از معدود مطالعات مشابه با مطالعه حاضر است، قابليت آموزشيذيرى حافظه كارى در هر آريا
هدف مطالعه حاضر بررسى اثر مداليته و نحوه ارائه اطلاعات در حافظه

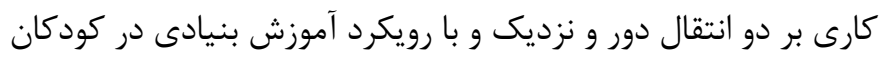

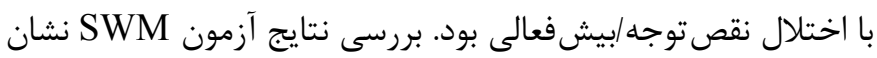
داد كه متغير خطاى كلى كه شاخصى از ظرفيت حافظه كارى ديدارى فضايى است، بعد از اجراى مداخله بهبود قابلتوجهى را در دو تروه آموزشى نشان مىدهد. اين يافته با ساير مطالعات و فراتحليلهاى براى

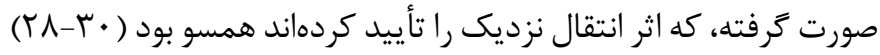
(يززوهشكران معتقدند يكى از مواردى كه در محدوديت ظرفيت حافظه كارى موثر است، اتصال ناكافى بين اجزاء بازنمايىها به معناى اتصال

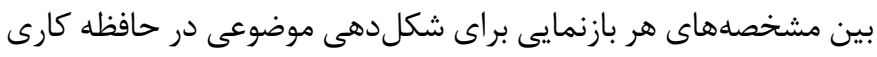

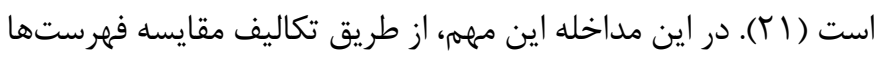

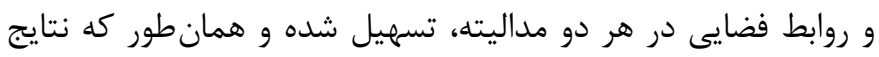
نشان مىدهد انتقال نزديك به عملكردهاى مشابه حافظه كارى در دران آزمون SWM صورت كَرفته است. اما آنجه مطالعه حاضر را از مطالعات

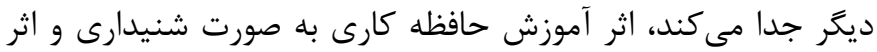


و بر مبناى نظريه تشخيص علامت بررسى شد. تشخيص ادراكى هدف كه با A' شناخته مىشود با محتواى حافظه كارى در ارتباط بوده و

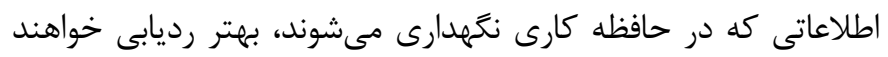

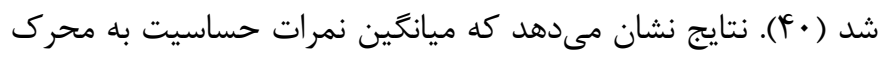

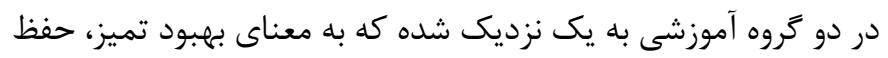
و رديابى توالىهاى عددى از ميان محركهاى اضافه است (شكل ז). مقايسهاى درون گروهى، تفاوت معنادارى را بين دو كروه آموزشى با دو كروه كنترل نشان داد كه اين نتايج، همسو با مطالعه كذشتنه، قابليت آموزشيذيرى اين شاخص را تأييد مىكنند (أl). همجنين اين يافته بر نظريه Unsworth و Engle كه ظرفيت حافظه كارى را دو روند همزمان حفظ توجه بر اطلاعات مرتبط و سركوب اطلاعات نامرتبط و لران

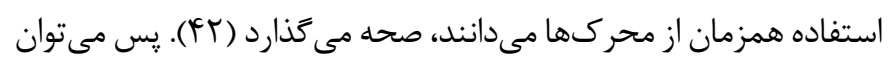

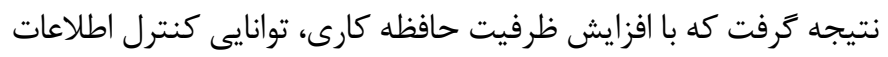
مرتبط و نامرتبط و حفظ توجه بر محرك هاى مختلف محيطى افزايش

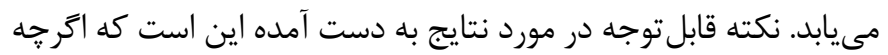
شاخص حساسيت به محرك ديدارى، شاخصى است كه بر عملكردهاى توجهى ديدارى تكيه دارد اما آزمودنىهاى گروه شنيدارى نيز به طوري

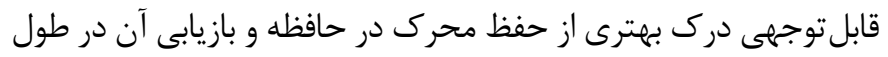

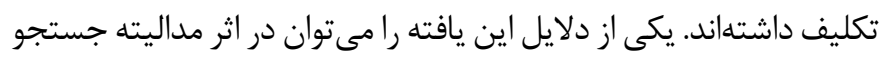

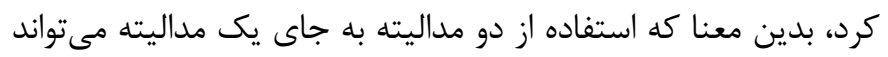

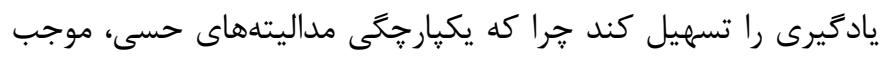

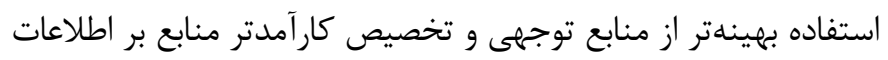

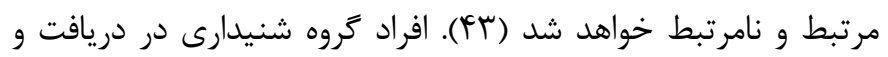
حفظ اطلاعات شنيدارى با مشكل مواجهه بودهاند و با بهبود عملكردهاى تهري حافظه كارى (حفظ، دستكارى و جلوكيرى از اطلاعات مرتبط) كه از طريق شنيدارى ارائه مى شدند، توانايى حفظ توجه بر محر كهاى ديدارى

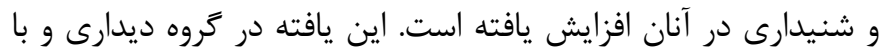

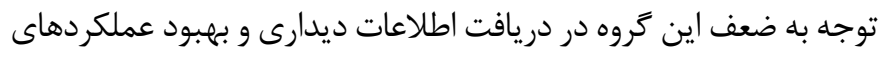
توجهى بعد از مداخله، طبيعى به نظر مىرسد اما در كروه شنيدارى علاوه

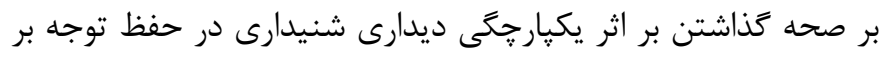

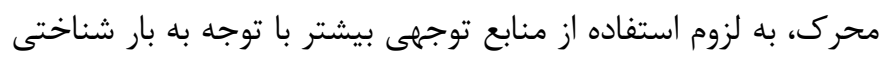
بالاترى كه براى دركير شدن در تكاليف شنيدارى لازم است اشاره دارد. يكى از مهمترين عواملى كه مىبايست در مطالعات بعدى مورد توجه قرار كيرد، مبحث دوام مهارتهاى كسب شده است. توجه به دوام اطلاعات در طول زمان براى مداخلات شنيدارى و ديدارى و با توجه به بارشناختى بيشترى كه مداخلات شنيدارى تحميل مى كنند، اهميت بالايى در

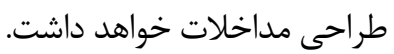

دو مداليته را تأييد مى كند. آن جه Schneider در بررسى اثر آموزش

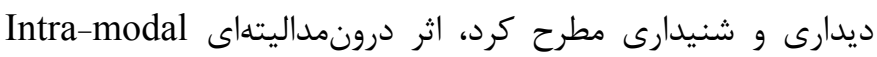

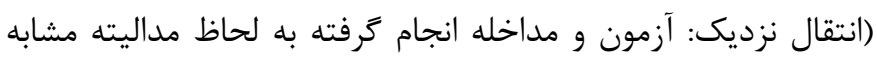
باشند) و برونمداليتهاى Across-modal (انتقال دور: آزمون و مداخله مدانه مدانه

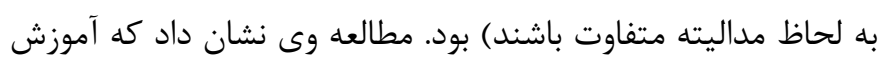
حافظه كارى به صورت شنيدارى در زمان محدود (1 جلسه درمانى) برخلاف آموزش ديدارى (1))، قابليت تعميم برونمداليتهاى را ندارد (19). با توجه به اين كه تفاوت معنادارى بين نتايج كروههاى ديدارى و شنيدارى مشاهده نمىشود، مىتوان نتيجه كرفت كه با افزايش طول جلسات، نه تنها انتقال نزديك (درونمداليتهاى) در گروه ديدارى بلكه

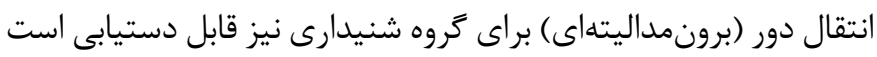

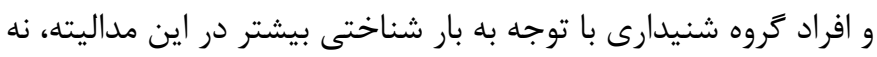

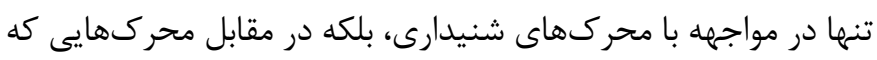
ماهيت حسى متفاوتى دارند بهتر عمل كردهاند. اما در شاخص استفاده از راهبرد كه يكى از شاخصهاى عملكردهاى

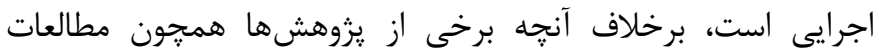
Klingberg از اثر آموزش حافظه كارى بر اين شاخص خبر مىدهند

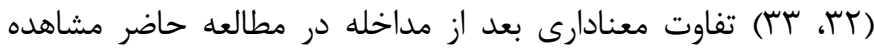

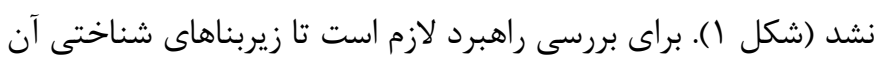

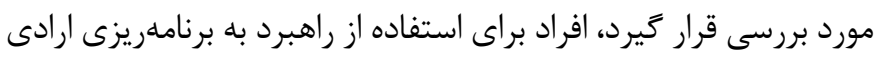

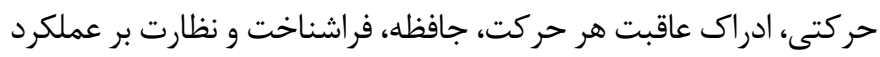

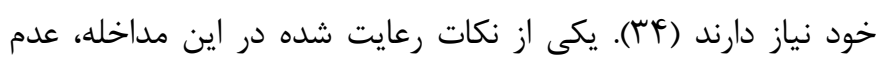

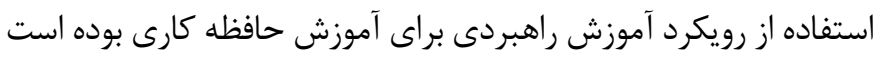

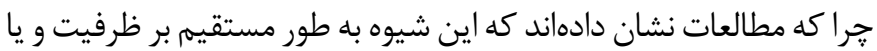
كار آيى حافظه كارى اثركذار نبوده و قابليت تعميميذيرى آموزش به ساير

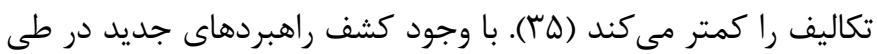
جلسات و براى پيشبرد مراحل مختلف تكاليف، در نظر گرفتن فراشناخت

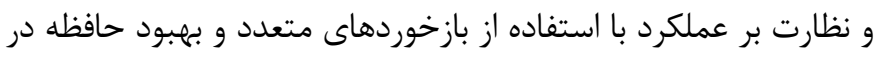

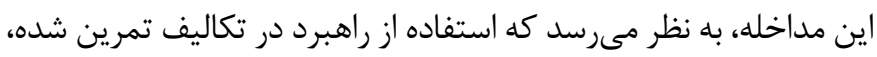

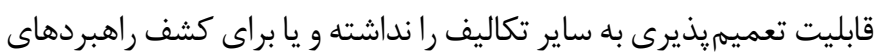

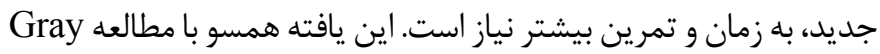

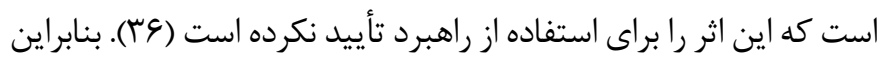

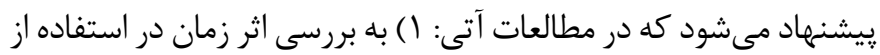

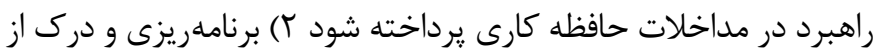
عاقبت عملكرد در اين مداخلات بيشتر مورد توجه قرار كَيرد.

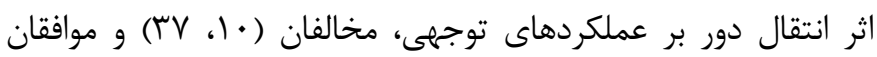

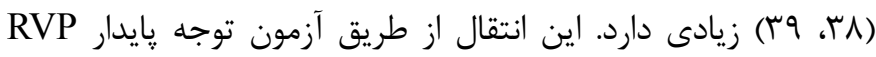


مهمترين محدوديتهاى مطالعه حاضر، تعداد افراد شركت كننده در هر گروه بود، ييشنهماد مىشود مطالعه حاضر با تعداد افراد بيشتر مجددأ تكرار شود. همجنين استفاده از مقياسهايى كه در شرايط غيرآزمايشخاهى (طبيعى) مىتواند عملكرد افراد را مورد ارزيابى قرار دهد، توصيه مىشوند.

\section{نتيجمه كيمرى}

نتايج به دست آمده از مطالعه حاضر، مداليته محور بودن آموزش حافظه كارى را نشان داد كه مشخص مى كند نوع مداليته ارائه شده در تعيين نتايج اثر كذار است. بنابراين لازم است قبل از شروع مداخلات، وضعيت افراد در توجه ديدارى و شنيدارى مشخص و بر مبناى ميزان نواقص در هر مداليته، مداخلات اعمال گردد. جرا كه در روند يادگيرى، تفاوتهاى فردى در تجربيات قبل از يادگيرى و يا مواجهه با مداليتههاى مختلف اهميت بالايى دارد كه همين عامل مىتواند بر دريافت، حفظ و توجه بر محركهاى محيطى اثرگذار بوده و در نهايت منجر به از دست دادن بسيارى از اطلاعات محيطى شود كه از طريق مداليته غيرغالب دريافت مىشوند. بر اين اساس دريافت يكيار جه اطلاعات از دو كانال ديدارى و شنيدارى اهميت بسزايى دارد، بنابراين اگر فردى در توجه، مهار و حفظ اطلاعات شنيدارى نقايص بيشترى در مقايسه با اطلاعات ديدارى داشته باشد، آموزش حافظه كارى از كانال ديدارى به تنهايى كارآمد نخواهد بود. بنابراين توصيه مىشود در مداخلات حافظه كارى به تفاوتهاى فردى و اثر مداليته بر نتايج، توجه شود.

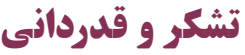

اين مطالعه با حمايت مالى ستاد علوم و فناورىهاى شناختى با كد طرح اع人^و همكارى بيمارستان ضيائيان تهران خصوصأ بخش تكامل

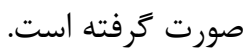

\section{References}

1. Xu G, Strathearn L, Liu B, Yang B, Bao W. Twenty-year trends in diagnosed attention-deficit/hyperactivity disorder among US children and adolescents, 1997-2016. JAMA Network Open. 2018;1(4):e181471.

2. Yadegari N, Sayehmiri K, Azodi MZ, Sayehmiri F, Modara F. The Prevalence of attention deficient hyperactivity disorder among iranian children: A meta-analysis. Iranian Journal of Psychiatry and Behavioral Sciences. 2018;12(4):10-18.
شاخص سو گيرى به ياسخ گويى را با مهار يا عدم مهار حر كتى در مواجهه با شرايط دشوار مرتبط مىدانند و اين شاخص مىتواند نمايندهاى براى رفتارهاى تكانشى يا غير تكانشى باشد (FF). شاخص سوگيرى به رويكرد فرد در ياسخ گويى اشاره دارد بدين معنا كه نمرات نزديك به يك، كاهش سو گيرى و نمراتى نزديك به صفر، افزايش سوخيرى به سمت ياسخ مثبت و رويكرد بىيرواتر در پاسخ گَويى (رفتار تكانشى در

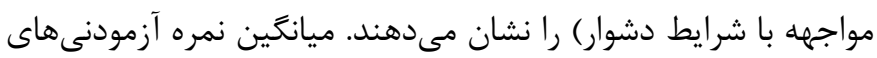
در شاخص سوگيرى در گروههاى ديدارى و شنيدارى به يك نزديك شد و به نظر مىرسد با بهبود عملكرد حافظه كارى رفتارهاى تكانشى و فاقد تصميمَّيرى كاهش مىيابد. گرجه شاخص حساسيت به محرك و سو گيرى دو شاخص مستقل از هم در نظر گرفته مىشوند اما شناسايى هدف به طور اختصاصى و مهار محركهاى نامرتبط عواملى هستند كه در سوگيرى اثرگذار هستند. توجه به اين نكته كه تفاوت معنادارى بين دو گروه ديدارى و شنيدارى مشاهده نمىشود به معناى كارآمدى مداخلات شنيدارى در رفتارهاى تكانشى و كنترل رفتار، همراستا با مداخلات از طريق ديدارى است. با اين حال، بسنده كردن به نتايج در شرايط آزمايشگاهى كافى به نظر نمىرسد و لازم است آزمودنىها در شرايط تنشزاى محيطى نيز مورد بررسى قرار گيرند. دو شاخص A' و "م، بر مبناى نظريه تشخيص علامت، مكانيسمهاى زير بنايى روند تصميم گيرى در شرايط نامطمئن هستند. بنابراين جون هر دو شاخص در يس آزمون بهبود قابل توجهى را نشان مى دهند مىتوان نتيجه گرفت كه با بهبود ظرفيت حافظه كارى، روند تصميمگيرى در شرايط حساس در كودكان با اختلال نقصتوجه/بيشفعالى، به طور قابلتوجهى تسهيل مىشود. همجنين يكيارجى اطلاعات در فضاى حافظه كارى و در نتيجه تخصيص منابع توجهى بر محرك هدف از طريق اطلاعات وارد شده توسط هر دو مداليته، مى تواند عاملى تعيين كننده بر نتايج باشد. يكى از

3. Mannuzza S, Klein RG, Moulton III JL. Persistence of attention-deficit/hyperactivity disorder into adulthood: What have we learned from the prospective follow-up studies?. Journal of Attention Disorders. 2003;7(2):93-100.

4. Castellanos FX, Sonuga-Barke EJ, Milham MP, Tannock R. Characterizing cognition in ADHD: Beyond executive dysfunction. Trends in Cognitive Sciences. 2006;10(3):117-123.

5. De Crescenzo F, Cortese S, Adamo N, Janiri L. Pharmacolog- 
ical and non-pharmacological treatment of adults with ADHD: A meta-review. Evidence-Based Mental Health. 2017;20(1):4-11. 6. Rapport MD, Chung KM, Shore G, Isaacs P. A conceptual model of child psychopathology: Implications for understanding attention deficit hyperactivity disorder and treatment efficacy. Journal of Clinical Child \& Adolescent Psychology. 2001;30(1):48-58.

7. Barkley RA. Behavioral inhibition, sustained attention, and executive functions: Constructing a unifying theory of ADHD. Psychological Bulletin. 1997;121(1):65-94.

8. Awh E, Vogel EK, Oh SH. Interactions between attention and working memory. Neuroscience. 2006;139(1):201-208.

9. Postle BR, Awh E, Jonides J, Smith EE, D’Esposito M. The where and how of attention-based rehearsal in spatial working memory. Cognitive Brain Research. 2004;20(2):194-205.

10. Lavie N, Hirst A, De Fockert JW, Viding E. Load theory of selective attention and cognitive control. Journal of Experimental Psychology: General. 2004;133(3):339-354.

11. Vogel EK, Fukuda K. In mind and out of phase. Proceedings of the National Academy of Sciences. 2009;106(50):2101721018.

12. Spencer-Smith M, Klingberg T. Benefits of a working memory training program for inattention in daily life: A systematic review and meta-analysis. PloS One. 2015;10(3):e0119522.

13. Sweller J. Cognitive load during problem solving: Effects on learning. Cognitive Science. 1988;12(2):257-285.

14. Mayer RE, Fiorella L. 12 principles for reducing extraneous processing in multimedia learning: Coherence, signaling, redundancy, spatial contiguity, and temporal contiguity principles. In The Cambridge handbook of multimedia learning. Vol. 279. Cambridge:Cambridge University Press;2014.

15. Wu SM, Ding HM, Tseng YL. A functional near-infrared spectroscopy study of auditory working memory load. In International Conference on Human-Computer Interaction. Cham, Switzerland:Springer, Cham;2017. pp. 273-277

16. Osman H, Sullivan JR. Children's auditory working memory performance in degraded listening conditions. Journal of Speech,
Language, and Hearing Research. 2014;57(4):1503-1511.

17. Witteman MJ, Segers E. The modality effect tested in children in a user paced multimedia environment. Journal of Computer Assisted Learning. 2010;26(2):132-142.

18. Lin HY, Hsieh HC, Lee P, Hong FY, Chang WD, Liu KC. Auditory and visual attention performance in children with ADHD: The attentional deficiency of ADHD is modality specific. Journal of Attention Disorders. 2017;21(10):856-864.

19. Schneiders J, Opitz B, Tang H, Deng Y, Xie C, Li H, et al. The impact of auditory working memory training on the fronto-parietal working memory network. Frontiers in Human Neuroscience. 2012;6:173.

20. Schneiders JA, Opitz B, Krick CM, Mecklinger A. Separating intra-modal and across-modal training effects in visual working memory: An fMRI investigation. Cerebral Cortex. 2011;21(11):2555-2564.

21. Wheeler ME, Treisman AM. Binding in short-term visual memory. Journal of Experimental Psychology: General. 2002;131(1):48-64.

22. Kaufman J, Birmaher B, Brent D, Rao UM, Flynn C, Moreci P, et al. Schedule for affective disorders and schizophrenia for school-age children-present and lifetime version (K-SADS-PL): Initial reliability and validity data. Journal of the American Academy of Child \& Adolescent Psychiatry. 1997;36(7):980-988.

23. Ghanizadeh A. ADHD, bruxism and psychiatric disorders: Does bruxism increase the chance of a comorbid psychiatric disorder in children with ADHD and their parents?. Sleep and Breathing. 2008;12(4):375-380.

24. Sohlberg MM, Mateer CA. Effectiveness of an attention-training program. Journal of Clinical and Experimental Neuropsychology. 1987;9(2):117-130.

25. Bakhshi S. Effect of selected attention-related tasks on sustained attention in children with attention deficit hyperactive disorder [BSc Thesis]. Tehran: University of Social Welfare and Rehabilitation Sciences;2010. (Persian)

26. Fried R, Hirshfeld-Becker D, Petty C, Batchelder H, Bie- 
derman J. How informative is the CANTAB to assess executive functioning in children with ADHD? A controlled study. Journal of Attention Disorders. 2015;19(6):468-475.

27. Rhodes SM, Coghill DR, Matthews K. Neuropsychological functioning in stimulant-naive boys with hyperkinetic disorder. Psychological Medicine. 2005;35(8):1109-1120.

28. Sala G, Gobet F. Working memory training in typically developing children: A meta-analysis of the available evidence. Developmental Psychology. 2017;53(4):671-685.

29. Salminen T, Strobach T, Schubert T. On the impacts of working memory training on executive functioning. Frontiers in Human Neuroscience. 2012;6:166.

30. Soveri A, Antfolk J, Karlsson L, Salo B, Laine M. Working memory training revisited: A multi-level meta-analysis of n-back training studies. Psychonomic Bulletin \& Review. 2017;24(4):1077-1096.

31. Julesz B, Hirsh I.J. Visual and auditory perception: An essay of comparison. In David EE, Denes PB, editors. Human communication: A unified view. New York:McGraw-Hill;1972. pp. 283-340. 32. Klingberg T, Forssberg H, Westerberg H. Training of working memory in children with ADHD. Journal of Clinical and Experimental Neuropsychology. 2002;24(6):781-791.

33. Klingberg T, Fernell E, Olesen PJ, Johnson M, Gustafsson P, Dahlström K, et al. Computerized training of working memory in children with ADHD-a randomized, controlled trial. Journal of the American Academy of Child \& Adolescent Psychiatry. 2005;44(2):177-186.

34. Pressley M, Harris KR. Cognitive strategies instruction: From basic research to classroom instruction. Journal of Education. 2009;189(1-2):77-94.

35. Carretti B, Borella E, De Beni R. Does strategic memory training improve the working memory performance of younger and older adults?. Experimental Psychology. 2007;54(4):311320.

36. Gray SA, Chaban P, Martinussen R, Goldberg R, Gotlieb H, Kronitz R, et al. Effects of a computerized working mem ory training program on working memory, attention, and academics in adolescents with severe LD and comorbid ADHD: A randomized controlled trial. Journal of Child Psychology and Psychiatry. 2012;53(12):1277-1284.

37. Shinaver III CS, Entwistle PC, Soderqvist S. Cogmed WM training: Reviewing the reviews. Applied Neuropsychology: Child. 2014;3(3):163-172.

38. Van Der Donk M, Hiemstra-Beernink AC, Tjeenk-Kalff A, Van Der Leij A, Lindauer R. Cognitive training for children with ADHD: A randomized controlled trial of cogmed working memory training and 'paying attention in class'. Frontiers in Psychology. 2015;6:1081.

39. Melby-Lervag M, Redick TS, Hulme C. Working memory training does not improve performance on measures of intelligence or other measures of "far transfer" evidence from a meta-analytic review. Perspectives on Psychological Science. 2016;11(4):512-534.

40. Soto D, Wriglesworth A, Bahrami-Balani A, Humphreys GW. Working memory enhances visual perception: Evidence from signal detection analysis. Journal of Experimental Psychology: Learning, Memory, and Cognition. 2010;36(2):441-456.

41. Savulich G, Thorp E, Piercy T, Peterson KA, Pickard JD, Sahakian BJ. Improvements in attention following cognitive training with the novel "decoder" game on an iPad. Frontiers in Behavioral Neuroscience. 2019;13:2.

42. Unsworth N, Engle RW. The nature of individual differences in working memory capacity: Active maintenance in primary memory and controlled search from secondary memory. Psychological Review. 2007;114(1):104-132.

43. Sepp S, Howard SJ, Tindall-Ford S, Agostinho S, Paas F. Cognitive load theory and human movement: Towards an integrated model of working memory. Educational Psychology Review. 2019:31;293-317.

44. Smillie LD, Jackson CJ. Functional impulsivity and reinforcement sensitivity theory. Journal of Personality. 2006;74(1):47-84. 